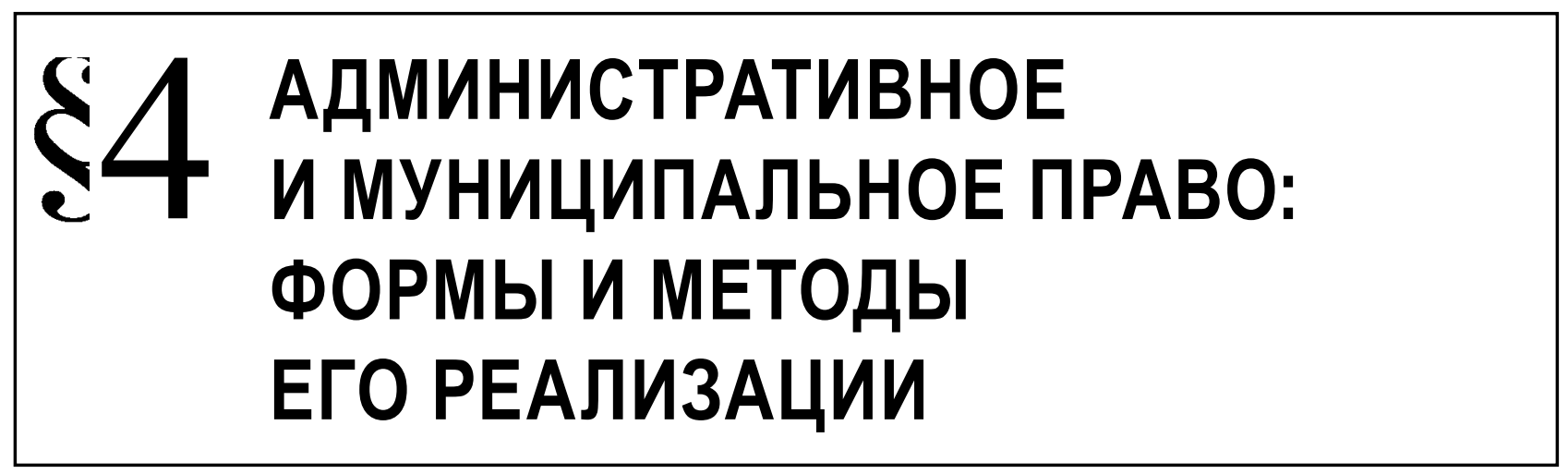

Булгакова К.Р.

\title{
К ВОПРОСУ О СУБЪЕКТАХ, ПРЕДОСТАВЛЯЮЩИХ МУНИЦИПАЛЬНЫЕ УСЛУГИ ВО ФРАНЦУЗСКОЙ РЕСПУБЛИКЕ И РОССИЙСКОЙ ФЕДЕРАЦИИ
}

Аннотация. В настоящее время в таких развитых странах Западной Европы, как Франция, и в Российской Федерации все действия государства в срере организации предоставления государственных и муниципальных услуг направлены на то, чтобы каждый знал и имел возможность требовать тот объем и то качество услуг, которые ему обязаны предоставить конкретные уровни власти. Предметом работы является изучение организации предоставления государственных и муниципальных услуг, а именно субъектов, осуществляющих их оказание. Цель - выявление особенностей организации предоставления государственных и муниципальных услуг во Франции и в России для предложений по совершенствованию законодательства. В процессе написания работы использованы сравнительно-правовой, диалектический, включающий приемы анализа и синтеза, индукции и дедукции, догматический методы, то есть исследование догмы права, законодательства и подзаконных нормативных актов, с лексическим и систематическим толкованием. Результаты работы: рассмотрены определения "публичная услуга», "государственная услуга», "муниципальная услуга»; выделены специальные субъекты, оказывающие муниципальные услуги во Франции: публичное учреждение (établissment public), концессионер по соответствующему договору "аутсорсинг», частная компания по договору "аффрермажа», а также группа публичного интереса (groupement de l'intérêt public); выявлена необходимость законодательного закрепления в качестве субъектов, оказывающих муниципальные услуги: коммерческие и некоммерческие структуры, которым могут быть предоставлены необходимые полномочия с помощью аутсорсинга или афрермажа (данный положительный опыт делегирования полномочий во Франции стоит принять во внимание при организации предоставления услуг в Российской Федерации); на основе анализа субъектов, предоставляющих муниципальные услуги в Российской Федерации, выявлены принципы, которым должен соответствовать субъект, предоставляющий муниципальные услуги:- приоритет прав и свобод человека и гражданина;- профессионализм и компетентность лии, предоставляющих услуги; - прикрепленность к определенному уровню администрации (государственному, региональному или местному); - непрерывность услуги (преемственность);- постоянная адаптация.Область применения результатов: дальнейшее совершенствования федерального законодательства в срере организации предоставления муниципальных услуг, а также создание основы для систематизации точек зрения ученых по данной проблематике.Выводы: детализированы субъекты предоставления муниципальных услуг от органов государственной власти и органов местного самоуправления до частных организаций, которым специальными способами переданы полномочия в исследуемой сфере.

Ключевые слова: муниципальная услуга, публичная услуга, государственная услуга, публичное учреждение, афрермаж, аутсорсинг, группа публичного интереса, ассоциации, некоммерческое партнерство, межмуниципальное сотрудничество.

Abstract. At the present time, the governments in such developed countries of Western Europe as France, and in the Russian Federation do everything they can for everyone to know and have the opportunity to claim the sufficient volume and quality of services from every particular level of authority. The research subject is the study of state and municipal services rendering and the subjects of rendering. The purpose of the research is to reveal the peculiarities of organization of state and municipal services rendering in France and in Russia and to offer the ways of the legislation 
improvement. The author applies comparative-legal, dialectical methods, analysis, synthesis, induction, deduction and dogmatic method, i.e. the study of the provisions of law, legislation and subordinate legis/ation with a further lexical and system interpretation. The author considers the "public service", "government service", "municipal service" concepts; outlines special subjects, rendering municipal services in France: a public institution (établissment public), a concessionary by an outsourcing agreement, a private company by affermage agreement, a public interest group (groupement de l'intérêt public). The author states the necessity to legislate commercial and non-commercial structures, which can be granted all the necessary authorities via outsourcing or affermage, as the subjects, rendering municipal services (this positive experience of delegation of powers in France should be taken into account in Russia when organizing services rendering). Based on the analysis of the subjects, rendering municipal services in Russia, the author detects the principles which the subject, delivering municipal services, should observe: - the priority of human and civil rights and freedoms; - professionalism and competence of persons delivering services; - linkage to a certain administration level (state, regional or local); - continuity of a service; - permanent adaptation.The results of the study can be used for a further improvement of federal legislation in the sphere of municipal services rendering, and as a basis for scholars' opinions systematization. The author specifies the subjects, delivering municipal services ranging from public and local authorities to authorized private companies.

Key words: intermunicipal cooperation, noncommercial partnership, associations, public interest group, outsourcing, affermage, public institution, state service, public service, municipal service.

$\mathrm{O}$ сновной целью демократического государства является создание условий на признание и обеспечение суверенитета (полновластия) народа, прав и свобод человека и гражданина. Конституция Российской Федерации [1] закрепляет целый ряд положений, обусловливающих демократический характер российского государства: возложение на государство, его органы и должностных лиц обязанности признавать, соблюдать и защищать права и свободы человека и гражданина (ст. 2); признание многонационального народа носителем суверенитета и единственным источником власти в РФ (ч. 1 ст. 3); закрепление за народом права осуществлять свою власть (реализовывать суверенитет) как непосредственно, так и через органы государственной власти и органы местного самоуправления (ч. 2 ст. 3); закрепление принципа разделения властей (ст. 10); конституционная возможность граждан участвовать в управлении делами государства (ч. 1 ст. 32). В соответствии с этими нормами, государственные органы, органы местного самоуправления и организации, которым предоставлены соответствующие полномочия, обеспечивают социальную защищенность всех граждан, достойную жизнь и свободное развитие человека, а также помогают осуществлять права человека и гражданина, дарованные Конституцией Российской Федерацией.

Реализуя следующие права: право на образование, медицинскую помощь, население вступает с государством в отношения, в которых государство посредством органов государственной власти, органов местного самоуправления, коммерческих и некоммерческих организаций оказывает государственные и муниципальные услуги, или как их принято называть в западных странах «публичные услуги» или «универсальные услуги». Понятие «универсальная услуга» введено в 1992г.
Европейской комиссией $[9$, с. 383] и определено как: минимальная услуга, установленного качества, предоставляемая любому пользователю за доступную цену. Во Франции понятие «публичная услуга» используется в материальном и формальном смысле. В материальном смысле публичная услуга - любая деятельность, направленная на удовлетворение потребности, представляющей общий интерес. В формальном смысле: публичная услуга - организованная совокупность материальных и человеческих ресурсов, применяемых государством или иным публичным коллективом в целях исполнения их задач. В большинстве зарубежных стран изучаемые услуги представляют собой вид взаимоотношений гражданина и/или юридического лица и власти, где государство рассматривается как «поставщик услуг», в Российской Федерации данные отношения являются новыми и такие термины, как «публичные услуги», «государственные услуги» и «муниципальные услуги» начинали использоваться только в процессе проведения реформ системы государственной службы Российской Федерации. В 2004г. Указом Президента Российской Федерации № 314 от 9 марта 2004г. «0 системе и структуре федеральных органов государственной власти» [6], даны определенные разъяснения, в том числе, что следует понимать под функциями по оказанию государственных услуг. В 2010г. принят Федеральный закон № 210-Ф3 «Об организации предоставления государственных и муниципальных услуг» [2], представивший определения понятиям «государственная услуга», «муниципальная услуга», «многофункциональные центры», «универсальная электронная карта». В соответствии со ст. 2 указанного закона: государственная услуга - деятельность по реализации функций соответственно федерального органа исполнительной власти, государственного внебюд- 


\section{Административное и муниципальное право 7 (103) • 2016}

жетного фонда, исполнительного органа государственной власти субъекта Российской Федерации, а также органа местного самоуправления при осуществлении отдельных государственных полномочий, переданных федеральными законами и законами субъектов Российской Федерации (далее органы, предоставляющие государственные услуги), которая осуществляется по запросам заявителей в пределах установленных нормативными правовыми актами Российской Федерации и нормативными правовыми актами субъектов Российской Федерации полномочий органов, предоставляющих государственные услуги; муниципальная услуга, предоставляемая органом местного самоуправления является деятельность по реализации функций органа местного самоуправления, которая осуществляется по запросам заявителей в пределах полномочий органа, предоставляющего муниципальные услуги, по решению вопросов местного значения, установленных в соответствии с Федеральным законом от 6 октября 2003 года № 131-Ф3 «Об общих принципах организации местного самоуправления в Российской Федерации» [3] и уставами муниципальных образований.

В настоящее время все действия Российского и Французского государств в сфере организации предоставления государственных и муниципальных услуг направлены на то, что каждый гражданин будет знать и иметь возможность требовать тот уровень, тот объем и то качество услуг, которые ему обязаны предоставить конкретные уровни власти. Для создания условий, улучшающих жизнь граждан Франция приняла нормативно-правовые акты об организации предоставления услуг, предоставляемых государством через государственные органы и органы местного самоуправления. Так, Советом Министров Франции в 1992г. была разработана Хартия о предоставлении государственных услуг, а в 1997г. была разработана Хартия качества услуг, в которой определены субъекты, оказывающие услуги.

Во Франции муниципальные услуги предоставляются публичными службами: центральные и местные структуры, к которым относятся системы правосудия, полиции, образования, здравоохранения, а также железнодорожный транспорт и энергетика. Муниципальные услуги оказываются прямым управлением коммун либо с помощью формальной приватизации или функциональной приватизации частным компаниям. Субъектом, предоставляющим муниципальные услуги помимо государственных и муниципальных органов, может выступать публичное учреждение (établissment public), концессионер по соответствующему договору аутсорсинга (концессионером может быть как субъект частного права, так и субъект публичного права) [18, p. 39], частная компания по договору «аффермажа», а также группа публичного интереса (groupement de l'intérêt public) [15, p. 287].

Фурнье отмечал, что публичными учреждениями обычно являются предприятия, которые осуществляют муниципальные услуги [10]. Публичное учреждение (établissment public) представляет собой одну из самых оригинальных категорий французского права. В контексте французского права публичным учреждением следует признать, например, университет. Во Франции публичные учреждения имеют специальную правоспособность, так как они не могут заниматься деятельностью, которая не указана в их учредительных документах. Таким образом, они не могут осуществлять права, не связанные с предметом их непосредственной деятельности. В соответствии с французским законодательством, публичное учреждение должно отвечать трем принципам [12]:

1) принципу автономии, что означает наличие собственной правосубъектности, собственных органов управления (совет администрации, директор), собственных бюджетных источников (регулярные взносы пользователей, банковские займы);

2) принципу прикрепленности к определенному уровню администрации (государственный, региональный или коммунальный); данный принцип уравновешивает принцип автономии и подчиняет соответствующее публичное учреждение территориальному коллективу, вместе с тем принцип прикрепленности не означает, что публичное учреждение государственного уровня не может оперировать на региональном или коммунальном уровне, и наоборот;

3) принципу специализации означает, что сфера полномочий каждого публичного учреждения носит четко ограниченный характер, поскольку список компетенций публичного учреждения всегда является закрытым [14, р. 4].

Обращаясь, к российскому законодательству, отметим, что Конституция РФ предусматривает специальную организационно-правовую форму осуществления муниципальной социальной политики - муниципальные учреждения, например в сферах образования и здравоохранения (ч. 1 ст. 41, ч. 2 и ч. 3 ст. 43). Данные учреждения обеспечивают выполнение возложенных на конкретный уровень муниципальной власти, полномочий, имеющих не административно-политический, а особый социально-управленческий характер. Они реализуют свою определенную долю специфического управленческого содержания. Следует поддержать концептуальную позицию В. Е. Чиркина [11, с. 252-253], согласно которой муниципаль- 
ные учреждения, хотя и не обладают формами принуждения, которые вправе использовать органы муниципальной власти, все же осуществляют специфическую муниципальную власть; это своего рода исполнительная власть, но она имеет частичный, специализированный и индивидуализированный характер. Она осуществляется методами в основном духовного воздействия, общесоциального управления в виде ориентирования, воспитания, помощи.

Муниципальные учреждения, обладая общими признаками, свойственными публичным учреждениям, являются одновременно необходимой составной частью местного самоуправления в Российской Федерации, то есть в сопоставлении с публичными учреждениями это более узкая по объему и более глубокая по своему содержанию правовая категория. Они обеспечивают самостоятельное решение населением вопросов местного значения, владение, пользование и распоряжение муниципальной собственностью, в них находит свое непосредственное выражение понимание местного самоуправления, как своего рода сервисного уровня публичной власти. Муниципальные учреждения выступают элементом муниципальной системы, через который в непосредственно представительных формах реализуется социальная функция муниципальной власти, осуществляется путем прямого предоставления социальных благ (оказания муниципальных услуг), в первую очередь в таких сферах, как здравоохранение и образование. Раскрывая конституционную природу муниципальных учреждений, следует подчеркнуть, что главным направлением деятельности, основной специализацией и самой сутью их работы является оказание населению муниципальных услуг, под которыми необходимо понимать специфическое правовое средство обеспечения непосредственной реализации конституционных прав граждан путем предоставления им на общедоступной, справедливой и равной основе индивидуализированных социальных благ. В этом плане муниципальные учреждения, используя правовые средства публичного обслуживания, напрямую подключаются к процессу муниципально-правового регулятивного воздействия на социально-экономические отношения и соучаствуют в осуществлении местного самоуправления. Необходимо понимать, что муниципальное обслуживание населения является решающим, смыслообразующим и целенаправляющим, фактором создания и деятельности муниципальных учреждений, однако не сводится только к публично-учрежденческой форме реализации. Такое обслуживание может осуществляться другими организациями немуниципальной формы собственности, которые выпол- няют или участвуют в выполнении публично значимых функций, то есть действуют в публичных интересах, а значит, входят в состав муниципальной системы жизнеобеспечения населения. Соответственно, должен соблюдаться разумный баланс в сфере публичного обслуживания с точки зрения соотношения в ней субъектов муниципальной и иной формы собственности в целях достижения оптимального равновесия ценностей, связанных с общедоступностью и качеством публичных услуг, а также решения посредством местного самоуправления иных конституционных задач, включая сохранение, освоение и развитие территорий. Поэтому во всяком случае должна быть обеспечена возможность предоставления муниципальных услуг посредством муниципальных учреждений: вопервых, в случаях, когда таковые прямо отнесены Конституцией РФ к субъектам обеспечения реализации тех или иных конституционных прав; вовторых, во всех прочих ситуациях, при которых изменение способа предоставления муниципальной услуги и переход от муниципально-учрежденческой формы их оказания к иной, государственной или частной, может повлечь за собой ухудшение социально-правового положения населения (в результате удорожания услуг, снижения их качества, доступности).

Второй вид субъектов: концессионеры по специальному договору - аутсорсинг [19, р. 200; 20]. По французскому праву можно представить следующие виды аутсорсинга:

1) аутсорсинг публичной службы;

2) аутсорсинг публичных работ;

3) аутсорсинг публичного имущества.

При аутсорсинге первого вида аутсорсер (концессионер) получает в управление определенную публичную службу, управляет ею на свой риск и получает доход за счет взносов пользователей. При аутсорсинге второго вида сначала аутсорсер инвестирует реализацию программы создания или развития определенной публичной службы, а затем в течение длительного времени возвращает свои инвестиции, часто с прибылью. Таким образом, аутсорсинг второго вида всегда имплицитно включает в себя аутсорсинг первого вида. Аутсорсинг третьего вида схож с понятием «аффермаж», с той разницей, что аутсорсер публичного имущества не может его эксплуатировать, а может только пользоваться. Во Франции наиболее распространен аутсорсинг на ведение общественных работ (concession de travaux publics) и аутсорсинг публичной службы (concession de service public). Аутсорсинг на ведение общественных работ напоминают государственный или муниципальный заказ на строительство объектов социальной инфраструктуры, производство разного рода работ. 


\section{Административное и муниципальное право 7 (103) • 2016}

Аутсорсинг публичной службы предполагают делегирование частному партнеру на определенный срок права на предоставление определенного рода услуг (например, водоснабжения, уборки мусора, энергосбережения). В настоящее время во Франции на основе аутсорсинга работает система газоснабжения и водоотведения, строятся школы, больницы, стадионы и тюрьмы.

В России аутсорсинг упоминается в программных документах органов власти как инструмент снижения бюджетных расходов и оптимизации численности государственных и муниципальных служащих. В частности, в законодательных и нормативных актах речь идет о передаче функций органов исполнительной власти, которые не отнесены к основному виду деятельности, специализированным организациям, создаваемым для обслуживания одновременно нескольких органов, или размещении государственных заказов на соответствующие услуги (аутсорсинг). При этом аутсорсинг становится актуальным инструментом управления в России. Так, концепцией реформ на 2006-2010 гг. в РФ предусмотрено, что составляющей оптимизации функций органов исполнительной власти и органов местного самоуправления является разработка и обеспечение широкого применения аутсорсинга - механизма выведения определенных видов деятельности за рамки полномочий органов исполнительной путем заключения контрактов с внешними исполнителями на конкурсной основе. То есть отдельные государственные услуги и муниципальные услуги, оказываемые в настоящее время, могут быть переданы организациям, выигравшим конкурс на оказание той или иной публичной услуги. Таким образом, субъект, оказывающий услугу, может быть заменен. В настоящее время, можно выделить три основных вида аутсорсинга:

1. Аутсорсинг бизнес-процессов. Это передача аутсорсеру функций, не являющихся для муниципалитета основными. Например, уборка помещений, обеспечение питанием, управление претензиями.

2. Производственный аутсорсинг, который малоприменим, поскольку предполагает передачу в удаленное управление части основного процесса, а это чревато потерей ключевых компетенций, определяющих деятельность муниципальных образований.

3. IT-аутсорсинг, то есть передача информационных систем в управление специализированным организациям: обслуживание техники, поддержке и обслуживании информационных систем (почты, локальных сетей, web-ресурсов), разработке и обслуживании ПО, обеспечении компьютерной безопасности.
Муниципальные образования, в свою очередь, проявляет готовность перепоручить выполнение задач в сфере коммунальных услуг частным лицам и предприятиям. В связи с этим, можно выделить три основные модели аутсорсинга («приватизации»): организационная, функциональная (аутсорсинг) и материальная. Организационная приватизация заключается в том, что субъект публичного управления не освобождает себя от обязанности осуществления публичной задачи, однако для ее реализации создает (приобретает) юридическое лицо частного права. При функциональной приватизации (аутсорсинге) передача государственных или муниципальных функций юридическим лицам частного права осуществляется без участия государства в их уставном капитале. Эта модель приватизации используется в связи с тем, что государство не обладает определенными ресурсами, которые есть у лиц частного права. Передача функции может осуществляться как с наделением, так и без наделения властными полномочиями. Материальная приватизация осуществляется в связи с перегруженностью муниципалитета: происходит отказ от исполнения определенных задач с передачей их полностью в частную сферу. Материальная приватизация влечет за собой полную передачу публичной задачи в негосударственный сектор.

Третий вид субъектов, предоставляющих муниципальные услуги, представляет собой частные компании по договору «аффермажа», который во Французской Республике представляет собой разновидность договора аренды, который заключает, например, муниципалитет с субъектом частного права, как правило, компанией. По этому договору компания обязана осуществлять управление определенной публичной службой. От аутсорсинга аффермаж отличается тем, что компания по договору аффермажа появляется лишь на стадии менеджмента муниципальной услуги, т.е. не является инвестором. Компания обязана делать регулярные фиксированные выплаты администрации муниципалитета. Доход самой компании формируется за счет взносов пользователей. Аффермаж широко применяется для управления системами питьевой воды [16]. Для Российской Федерации понятие «аффермаж» имеет место быть в сфере государственно-частного партнерства, по своей правовой природе «аффермаж» аналогичен, но не идентичен лизинговому контракту в сфере гражданского права [8]. Стоит также обратить внимание на тот факт, что «аффермаж» регулируется на стыке государственного и гражданского права. В отличие от лизинга, где частный сектор удерживает доходы, собранные от клиентов, и осуществляет определенную арендную плату органу, с которым заключен контракт, аффермаж позволяет частному сек- 
тору собирать доходы от клиентов, выплачивать плату за аффермаж и оставлять себе оставшуюся часть доходов. Аффермаж может быть более привлекателен для частного партнера, так как он снижает некоторые риски, связанные с низким возмещением затрат при продажах.

Четвертый вид субъектов, предоставляющих услуги во Французской Республике представляют собой группу публичного интереса (ГПИ): юридическое лицо государственного и муниципального права sui generis. ГПИ представляет ассоциацию юридических лиц - форму, известную многим национальным правопорядкам. Специфика ГПИ лежит в ее публично-правовом статусе, хотя в нее могут входить как субъекты государственного и муниципального права, так и субъекты коммерческого права. Данная модель управления службой применяется в некоммерческом секторе (здравоохранение, социальное обеспечение, обслуживание информационных центров). В России, аналогию ГПИ можно провести с организационно-правовыми формами некоммерческих организаций, являющихся добровольным объединением юридических лиц и/или граждан с сохранением права последних вступать в другие объединения: ассоциации, союзы, некоммерческие партнерства. Разница в том, что данные организационно-правовые формы, к примеру некоммерческие партнерства созданы для содействия ее членам в осуществлении деятельности, направленной на достижение социальных, благотворительных, культурных, образовательных, научных и управленческих целей. Некоммерческое партнёрство может быть создано в целях охраны здоровья граждан, развития физической культуры и спорта, удовлетворения духовных и иных нематериальных потребностей граждан, защиты прав, законных интересов граждан и организаций, разрешения споров и конфликтов, оказания юридической помощи, а также в иных целях, направленных на достижение общественных благ.

Помимо выделенных субъектов, во Франции развиты формы межмуниципального сотрудничества [17]. В целях его упорядочения в 1990х гг. XX в. был принят ряд законов, наиболее значимым из них явился Закон о межкоммунальном сотрудничестве 1999г., закрепивший следующие виды межкоммунальных объединений:

1) сообщество коммун (communaute de communes), предназначенное для небольших, как правило, сельских, коммун;

2) агломерация коммун (communaute d'agglomeration), включающая в себя основную коммуну с населением не менее 15 тыс. жителей, а также прилегающие к ней пригороды;

3) городское сообщество (communaute urbaines), включающее в себя крупный город и его при- городы (минимальная численность жителей такого сообщества - 500 тыс.).

В настоящее время во Франции функционирует 2400 сообществ коммун, 174 агломерации коммун и 16 городских сообществ. Проведенная реформа была определена во французской литературе как «межмуниципальная революция», благодаря которой «местное управление во Франции постепенно превращается во все более сложную и дифференцированную систему, в рамках которой несколько тысяч межмуниципальных органов управления играют все более значимую роль» [13, р. 28].

В Российской Федерации межмуниципальное сотрудничество - один из векторов местного развития, заключающийся в поиске консенсуса между смежными территориями в целях совместного решения вопросов местного значения, например, в ассоциации сибирских и дальневосточных городов (АСДГ) создана рабочая группа по реформе ЖКХ [7]. Это сотрудничество осуществляется на основе взаимодействия муниципальных образований в различных правовых формах: заключение межмуниципальных соглашений, участие в межмуниципальных ассоциациях, создание совместных координационных органов. Вместе с тем несмотря на положительный эффект, который обеспечивает своим участникам межмуниципальное сотрудничество, подобное взаимодействие в настоящее время имеет достаточно ограниченное распространение. Потребность в межмуниципальном сотрудничестве с целью объединения ресурсов возникает, прежде всего, в связи: 1) с целесообразностью объединения финансовых ресурсов муниципальных образований ввиду недостаточности собственных финансовых средств отдельных муниципальных образований; 2) с необходимостью повышения качества и расширением видов предоставляемых населению муниципальных услуг; 3) с необходимостью использования «эффекта масштаба» (в отдельных случаях незначительное количество услуг или потребителей услуг приводит к отказу в их предоставлении, так как делает их оказание экономически невыгодным); 4) со сложной кадровой ситуацией в муниципальных образованиях. Для решения вопросов местного значения в Российской Федерации, в том числе задач по предоставлению муниципальных услуг, стоящих перед муниципальными образованиями, могут создаваться хозяйственные общества в форме закрытых акционерных обществ и обществ с ограниченной ответственностью. Для организации решения отдельных вопросов местного значения несколькими муниципальными образованиями могут также создаваться межмуниципальные некоммерческие организации в форме автономных некоммерческих организаций и фондов. 


\section{Административное и муниципальное право 7 (103) 2016}

Исходя из выше изученного, а также существующей практике по организации предоставлению муниципальных услуг, по нашему мнению, следует выделить основные принципы, которым должен соответствовать субъект, предоставляющие муниципальные услуги в Российской Федерации:

1) принцип приоритета прав и свобод человека и гражданина. Данный принцип основан на ст.2 Конституции РФ, которая гласит: «Человек, его права и свободы являются высшей ценностью. Признание, соблюдение и защита прав и свобод человека и гражданина - обязанность государства» и закреплен в Федеральном законе от 27 июля 2004 г. № 79-Ф3 «О государственной гражданской службе Российской Федерации» [4] и в Федеральном законе от 02.03.2007 № 25-Ф3 «0 муниципальной службе в Российской Федерации» [5]. Эту обязанность государство выполняет с помощью своих органов, функции и полномочия которых осуществляют работающие в них государственные служащие. Обязанность государства - это обязанность государственных служащих. В связи с этим приоритет прав и свобод человека и гражданина не только принцип и повседневное правило служебной деятельности в государственном аппарате, но и основополагающий фундамент при оказании государственных и муниципальных услуг населению. Всем своим содержанием предоставление государственных и муниципальных услуг должно способствовать реализации прав и свобод человека и гражданина. Муниципальные служащие в рамках полномочий органов местного самоуправления, определенных ФЗ № 131-Ф3, обязаны содействовать гражданам в реализации их прав при получении муниципальных услуг, призваны обеспечивать должную правовую процедуру реализации функций местного самоуправления, проводить консультативные работы с гражданами. Реализация данного принципа определяет социальный смысл и содержание профессиональной служебной деятельности муниципальных служащих.

2) Профессионализм и компетентность лиц, предоставляющих услуги. Федеральный закон от 27 июля 2004 г. № 79-ФЗ «0 государственной гражданской службе Российской Федерации» и в Федеральный закон от 02.03.2007 № 25-Ф3 «О муниципальной службе в Российской Федерации» устанавливают требования по отношению к государственным и муниципальным служащим: высшее образование, направление подготовки, профессиональный стаж, знания и навыки лиц, претендующих на занятие должности государственной гражданской или муниципальной службы. Однако в Федеральном законе № 210-ФЗ «Об организации предоставления государственных и муниципальных услуг» данный принцип не зафиксирован в отношении специальных организаций, которым делегированы определенные полномочия по оказанию государственных и муниципальных услуг. На наш взгляд, он должен быть отражен в их учредительных документах. Кроме того, профессионализм подразумевает и соблюдение поставщиками услуг соответствующих правил поведения, в том числе умение проявлять уважение к пользователям услуг.

3) Принцип прикрепленности к определенному уровню администрации (государственный, региональный или местный); указанный принцип существует во французском законодательстве и подчиняет коммерческую или некоммерческую организацию, оказывающую государственную или муниципальную услугу, соответствующему уровню администрации. Вместе с тем, это не означает, что организация государственного уровня не может оперировать на региональном или местном уровне, и наоборот.

4) Принцип непрерывности услуги (преемственности): предоставление муниципальной услуги будет осуществляться непрерывно в любое время вне зависимости от любых ситуаций. Этот принцип реализуется на практике, несмотря на отсутствие законодательного закрепления, с помощью многофункциональных центров, куда каждый может обратиться за предоставлением одной или нескольких государственных или муниципальных услуг, благодаря электронному сайту для предоставления государственных услуг в России - gosuslugi.ru и универсальным электронным картам (введены в оборот, но задействованы небольшим процентом пользователей в стране), а также сайтам субъектов Российской Федерации и муниципальных образований (не все из сайтов муниципальных образований предусматривают возможность получения муниципальной услуги он-лайн, однако многие имеют административные регламенты, описывающие такую возможность).

5) Принцип постоянной адаптации организации предоставления муниципальных услуг. То есть в случае увеличения числа потребителей услуг не должна быть уменьшена их полезность для каждого. Таким образом, организация предоставления муниципальных услуг должна учитывать современные реалии, быть гибкой в отношении всех изменений. 
Библиография:

1. Конституция Российской Федерации. Принята всенародным голосованием 12 декабря 1993 года // Собрание законодательства Российской Федерации. 2009. № 4. Ст. 445. С учетом поправок, внесенных Законами Российской Федерации от 30 дек. 2008 г. № 6-ФКЗ, от 30 дек. 2008 г. № 7-ФКЗ, от 5 февр. 2014 г. № 2-ФКЗ, от 21 июля 2014 г. № 11-ФКЗ.

2. Об организации предоставления государственных и муниципальных услуг: федер. закон: [принят Гос. Думой 7 июля 2010 г.: одобр. Советом Федерации 14 июля 2010 г.] // Собрание законодательства Российской Федерации. 2010. № 31. Ст. 4179. С учетом последующих изм.

3. Об общих принципах организации местного самоуправления в Российской Федерации: федер. закон: [принят Гос. Думой 16 сент. 2003 г.: одобр. Советом Федерации 24 сент. 2003 г.] // Собрание законодательства Российской Федерации. 2003. № 40. Ст. 3822. С учетом последующих изм.

4. $\quad$ о государственной гражданской службе Российской Федерации: федер. закон: [принят Гос. Думой 7 июля 2004 г.: одобр. Советом Федерации 15 июля 2004 г.] // Собрание законодательства Российской Федерации. 2004. № 31. Ст. 3215. С учетом последующих изм.

5. 0 муниципальной службе в Российской Федерации: федер. закон: [принят Гос. Думой 7 февр. 2007 г.: одобр. Советом Федерации 21 февр. 2007 г.] // Собрание законодательства Российской Федерации. 2007. № 10. Ст. 1152. С учетом последующих изм.

6. О системе и структуре федеральных органов исполнительной власти: указ Президента Российской Федерации от 9 марта 2004 г. // Собрание законодательства Российской Федерации. 2004. № 11. Ст. 945. С учетом последующих изм.

7. Устав Ассоциации сибирских и дальневосточных городов [Электронный ресурс]. Режим доступа: http://www. asdg.ru (дата обращения: 15.12.2015).

8. Делмон, Д. Государственно-частное партнерство в инфраструктуре. Практическое руководство для органов государственной власти [Электронный ресурс]. Режим доступа: http://www.ppiaf.org/sites/ppiaf.org/files/ publication/Jeff\%20Delmon_PPP_russian.pdf (дата обращения 15.01.2016).

9. Публичные услуги и право: науч.-практ. пособие / Ю. А. Тихомиров [и др.]; под ред. Ю. А. Тихомирова. - 2-е изд. М.: Норма, 2007. - 416 с. - ISBN 978-5-468-00106-6.

10. Фурнье, Ж. Предприятия публичного сектора в государствах Европейского союза / Ж. Фурнье // Участие государства в коммерческой деятельности / Российский фонд правовых реформ. - М., 2001. - С. 68-72.

11. Чиркин, В. Е. Юридическое лицо публичного права / В. Е. Чиркин. - М.: Норма, 2007. - 352 с. - ISBN 978-5-46800082-3.

12. Le Code général des collectivités territoriales (CGCT) [Электронный ресурс]. Режим доступа:http://legifrance.gouv.fr/ affichCode.do?cidTexte=LEGITEXT000006070633\&dateTexte=20151002 (дата обращения: 12.12.2012).

13. Borraz, O. France: The Inter-Municipal Revolution / Borraz O., Le Gales P. // Comparing Local Governance. Trends and developments. - France: Denters, B. \& Rose, L. E.: Macmillan, 2005. - P. 12-28.

14. Douence, J.-C. Le rattachement des établissements publics à une collectivité territoriale - le cas des établissements publics locaux / Douence J.-C. - [France]: AJDA, 1971. - 200 p.

15. Gaudemet, Y. Traite de droit administratif: 2 t. T. 1. Droit administratif general / Gaudemet Y. - 16 éd. - Paris: LGDJ, 2001. - $918 \mathrm{p}$.

16. La gestion de l'eau - Privée ou publique? [Электронный ресурс] // [Nouvel Economiste. - 2012. - 23 Févr]. - Peжим доступа: http://www.lenouveleconomiste.fr/lesdossiers/la-gestion-de-leau-privee-ou-publique-13815/ (дата обращения: 24.10.2011).

17. La gestion des services publics locaux d'eau et d'assainissement: rapport public particulier [Электронный ресурс] // [Cour des Comptes, 1997]. - Режим доступа: www.ccomptes.fr/Cour-des-comptes/publications/rapports/eau/cdc72. htm (дата обращения: 24.12.2012).

18. Lambert, Е. Droit coutumier contemporain. Du contrat en faveur de tiers, son fonctionnement, ses applications actuelles, cession de dette (délégation, cession de portefeuille, cession de bail), assurance-vie, assurance-accident, contrats d'utilité publique / Lambert E. - Paris: A. Giard \& E. Brière, 1893. - 421 p.

19. Richer, L. Droit des contrats administratifs / Richer Laurent. - 6e éd. - París: LGDJ, 2008. - 765 p. - ISBN 9782275032900.

20. Seyersted, F. Applicable Law in Relations between Intergovernmental Organizations and Private Parties / Frederick Seyersted // Academy of International Law. - 1967. - Nr. 122.

\section{References (transliterated):}

1. Konstitutsiya Rossiiskoi Federatsii.Prinyatavsenarodnymgolosovaniem 12 dekabrya 1993 goda//Sobranie zakonodatel'stva Rossiiskoi Federatsii. 2009. № 4. St. 445. S uchetom popravok, vnesennykh Zakonami Rossiiskoi Federatsii ot 30 dek. $2008 \mathrm{~g}$. № 6-FKZ, ot 30 dek. 2008 g. № 7-FKZ, ot 5 fevr. 2014 g. № 2-FKZ, ot 21 iyulya 2014 g. № 11-FKZ

2. Ob organizatsii predostavleniya gosudarstvennykh i munitsipal'nykh uslug: feder. zakon: [prinyat Gos. Dumoi 7 iyulya 2010 g.: odobr. Sovetom Federatsii 14 iyulya 2010 g.] // Sobranie zakonodatel'stva Rossiiskoi Federatsii. 2010 . № 31. St. 4179. S uchetom posleduyushchikh izm.

3. Ob obshchikh printsipakh organizatsii mestnogo samoupravleniya v Rossiiskoi Federatsii: feder. zakon: [prinyat Gos. Dumoi 16 sent. 2003 g.: odobr. Sovetom Federatsii 24 sent. 2003 g.] // Sobranie zakonodatel'stva Rossiiskoi Federatsii. 2003. № 40. St. 3822. S uchetom posleduyushchikh izm. 


\section{Административное и муниципальное право 7 (103) • 2016}

4. $\quad 0$ gosudarstvennoi grazhdanskoi sluzhbe Rossiiskoi Federatsii: feder. zakon: [prinyat Gos. Dumoi 7 iyulya 2004 g.: odobr. Sovetom Federatsii 15 iyulya 2004 g.] // Sobranie zakonodatel'stva Rossiiskoi Federatsii. 2004. № 31. St. 3215. S uchetom posleduyushchikh izm.

5. O munitsipal'noi sluzhbe v Rossiiskoi Federatsii: feder. zakon: [prinyat Gos. Dumoi 7 fevr. 2007 g.: odobr. Sovetom Federatsii 21 fevr. 2007 g.] // Sobranie zakonodatel'stva Rossiiskoi Federatsii. 2007. № 10. St. 1152. S uchetom posleduyushchikh izm.

6. O sisteme i strukture federal'nykh organov ispolnitel'noi vlasti: ukaz Prezidenta Rossiiskoi Federatsii ot 9 marta 2004 g. // Sobranie zakonodatel'stva Rossiiskoi Federatsii. 2004. № 11. St. 945. S uchetom posleduyushchikh izm.

7. Ustav Assotsiatsii sibirskikh i dal'nevostochnykh gorodov [Elektronnyi resurs]. Rezhim dostupa: http://www.asdg.ru (data obrashcheniya: 15.12.2015).

8. Delmon, D. Gosudarstvenno-chastnoe partnerstvo v infrastrukture. Prakticheskoe rukovodstvo dlya organov gosudarstvennoi vlasti [Elektronnyi resurs]. Rezhim dostupa: http://www.ppiaf.org/sites/ppiaf.org/files/publication/ Jeff\%20Delmon_PPP_russian.pdf (data obrashcheniya 15.01.2016).

9. Publichnye uslugi i pravo: nauch.-prakt. posobie / Yu. A. Tikhomirov [i dr.]; pod red. Yu. A. Tikhomirova. - 2-e izd. - M.: Norma, 2007. - 416 s. - ISBN 978-5-468-00106-6.

10. Furn'e, Zh. Predpriyatiya publichnogo sektora v gosudarstvakh Evropeiskogo soyuza / Zh. Furn'e // Uchastie gosudarstva v kommercheskoi deyatel'nosti / Rossiiskii fond pravovykh reform. - M., 2001. - S. 68-72.

11. Chirkin, V. E. Yuridicheskoe litso publichnogo prava / V. E. Chirkin. - M.: Norma, 2007. - 352 s. - ISBN 978-5-468-00082-3.

12. Le Code général des collectivités territoriales (CGCT) [Elektronnyi resurs]. Rezhim dostupa:http://legifrance.gouv.fr/ affichCode.do?cidTexte=LEGITEXT000006070633\&dateTexte=20151002 (data obrashcheniya: 12.12.2012).

13. Borraz, O. France: The Inter-Municipal Revolution / Borraz O., Le Gales P. // Comparing Local Governance. Trends and developments. - France: Denters, B. \& Rose, L. E.: Macmillan, 2005. - P. 12-28.

14. Douence, J.-C. Le rattachement des établissements publics à une collectivité territoriale - le cas des établissements publics locaux / Douence J.-C. - [France]: AJDA, 1971. - 200 p.

15. Gaudemet, Y. Traite de droit administratif: 2 t. T. 1. Droit administratif general / Gaudemet Y. - 16 éd. - Paris: LGDJ, 2001. - $918 \mathrm{p}$.

16. La gestion del'eau - Privée ou publique? [Elektronnyi resurs] // [Nouvel Economiste. - 2012. - 23 Févr.] - Rezhim dostupa: http://www.lenouveleconomiste.fr/lesdossiers/la-gestion-de-leau-privee-ou-publique-13815/ (data obrashcheniya: 24.10.2011).

17. La gestion des services publics locaux d'eau et d'assainissement: rapport public particulier [Elektronnyi resurs] // [Cour des Comptes, 1997]. - Rezhim dostupa: www.ccomptes.fr/Cour-des-comptes/publications/rapports/eau/cdc72.htm (data obrashcheniya: 24.12.2012).

18. Lambert, E. Droit coutumier contemporain. Du contrat en faveur de tiers, son fonctionnement, ses applications actuelles, cession de dette (délégation, cession de portefeuille, cession de bail), assurance-vie, assurance-accident, contrats d'utilité publique / Lambert E. - Paris: A. Giard \& E. Brière, 1893. - 421 p.

19. Richer, L. Droit des contrats administratifs / Richer Laurent. - 6e éd. - París: LGDJ, 2008. - 765 p. - ISBN 9782275032900.

20. Seyersted, F. Applicable Law in Relations between Intergovernmental Organizations and Private Parties / Frederick Seyersted // Academy of International Law. - 1967. - Nr. 122. 